\title{
Hiljainen taitotieto ja henkilöstön kehittäminen
}

\author{
Henkilöstön kehittämisellä tarkoitetaan sellaisia tietoisesti suunniteltuja \\ prosesseja, joiden oletetaan kehittävän henkilöstön pätevyyttä. Tietoisen \\ suunnittelun vaade ei edellytä, että kehittymisprosessin kulku olisi koko ajan \\ tarkassa seurannassa ja ohjannassa.
}

Henkilöstön kehittämistä voidaan tarkastella lyhyen ja pitkän aikajänteen näkökulmista. Lyhyen aikajänteen tarkastelussa näkökulmana on suunniteltu muutos ja sen toteuttaminen. Lähitulevaisuudessa tarvitaan uutta osaamista $\mathbf{j a} / \mathbf{t a i}$ asennoitumista. Tarpeen määrittelyn lähtökohtana ovat organisaation (erityisesti sen johdon) strategiset valinnat.

Pitkän aikajänteen tarkastelussa painottuu ennakoimattomuus. Työura kestää saman organisaation palveluksessa usein vuosikymmeniä. Uran kokonaistulos mitataan vasta sen päätyttyä. Perinteinen suunnittelun tavoite-keino -rationaalisuus, joka olettaa tietyn sisällöllisen tavoitteen kriteeriksi, ei toimi luontevasti pitkän aikajänteen tarkastelussa. Täsmällisten sisältöjen ohella ja lisäksi on keskityttävä prosessien ohjailuun. On kehitettävä työntekijää mutta myös myötävaikutettava ihmisen yleisempiin kehittymisen mahdollisuuksiin.

\section{Ennakoitava ja ennakoimaton oppiminen}

Henkilöstön kehittämisessä tavoiteltava oppiminen voidaan jakaa kahteen pääluokkaan: (1) ennakoitavaan, täsmälliseen ja kohtuullisen tarkasti määriteltävissä olevaan oppimiseen (lyhyen aikajänteen näkökulma) sekä (2) ennakoimattomaan, itseohjautuvaan oppimiseen, joka tapahtuu toiminnan myötä ja on usein vaikeasti havaittavaa tahi tiedostettavaa (pitkän aikajänteen näkökulma).
Ennakoimattomuuden käsitettä ei ole syytä mieltää absoluuttisena vaan relatiivisena, suhteellisena. Kyseessä on sellainen oppiminen, jonka tulokset ovat ennustettavissa ainoastaan laveasti: vuodessa organisaation uusi jäsen yleensä oppii talon tavoille. Tiedetään, että oppimista tapahtuu mutta ei välttämättä sitä, millaista, milloin ja missä se tapahtuu.

Ennakoitava ja ennakoimaton oppiminen kietoutuvat toisiinsa ja tukevat toisiaan. Niiden erilaisten ominaisuuksien tunteminen mahdollistaa tehokkaasti organisoidun, monipuolisia tuloksia niin yksilön kuin organisaationkin näkökulmasta tuottavan henkilöstön kehittämisen.

Ennakoimattoman, työssä tai muuten arkielämässä tapahtuvan oppimisen merkitystä herkästi vähätellään. On esitetty, että noin 80 prosenttia aikuisen oppimisesta on ennakoimatonta, tavallaan itsestään tapahtuvaa (Tough 1982). Tällöin ei kuitenkaan huomioida oppimisen laatua tahi alueita. Väite on siten ongelmallinen. Kuitenkin jos se pitää paikkansa edes osapuilleen, on henkilöstön kehittämisessä todella paneuduttava 
ennakoimattoman oppimisen tukemiseen ja suuntaamiseen.

Työssä oppiminen on valtaosaltaan ennakoimatonta oppimista. Oppimisella on sanana vahva myönteinen sivumerkitys, konnotaatio. Niinpä työssä oppimista pidetään pääsääntöisesti hyvänä asiana, joka edistää työsuoritusta. Käsittääkseni organisaatiot herkästi ehkäisevät työuran maksimaalisen kokonaispanoksen muodostumisen pitkän aikajänteen näkökulmasta tarkasteltuna. Seuraava aito tapausesimerkki luotaa asiaa. Samalla se kuvaa, miten työssä oppiminen vaikuttaa yksilön persoonallisuuteen (aiheesta enemmän Bandura 1989, Sköld 1989)

\begin{abstract}
Kokenut käytännön ammattilainen halusi vastuuhenkilön sairastuttua suorittaa muutaman päivän ajan omien töidensä ohella hänen työtehtäviään. Hän olisi nämä tehtävät taatusti osannut. Organisaatio kuitenkin kielsi: niitä tehtäviä hoitavat akateemisesti koulutetut työntekijät. Niinpä palkattiin muutamaksi päiväksi sijainen, jolle vastuuhenkilön tehtävät olivat outoja. Tutkinto sitä vastoin oli.

Organisaation ratkaisu ei ollut lainsäädännön pakottama. Suorituksen taso tai toiminnan kohteena olevien henkilöiden turvallisuus ei olisi vaarantunut. Ratkaisu oli vain ja toivoakseni - huomaamatta omaksuttu käytäntö.

Psykologinen viesti oli selvä. Tunne rajat. Älä yritä käyttää todellista osaamistasi vaan sopeudu rooliisi. Se määrittää toimintakelpoisuutesi, arvosi. Tuloksen teon mahdollisuudet oli kapeututettu - huomaamatta, pahaa tarkoittamatta mutta joka tapauksessa kapeututettu. Tahto, halu hyvään suoritukseen poisopetettiin tehokkaasti (Psykologisemmin tässä oli kyseessä ulkoisen kausaaliattribuoinnin juurruttaminen yksilöön, kiinnostavasta ongelmatiikasta enemmän Deci \& al. 1991, Parkes 1991, Varila \& al 1992 ja Vesala 1991).
\end{abstract}

Hiljaista tai piilevää tietoa käsitellyt keskustelu on tuonut saman problematiikan, työssä oppimisen luonteen ja laaja-alaisuuden, toisesta näkökulmasta esille (Koskinen 1989, Molander 1989, Sarala 1991, Sarvimäki 1988, Varila 1992). Sitä voidaan tarkastella myös asiantuntijuuden kehittymisenä - asiantuntijoilla on usein yllättävän suuria vaikeuksia perustella, miksi he ovat päätyneet tiettyyn ratkaisuun (asiantuntijuuden luonteesta kiinnostuneen lukijan kannattaa perehtyä Ropon 1991 artikkeliin, tässä aiheeseen ei voida enempää paneutua).

\section{Mitä on hiljainen taitotieto}

Hiljaisen tiedon käsitettä käytti ilmeisesti ensimmäisenä Polanyi (1966). Yhteiskuntatieteisiin käsite siirtyi 1970 -luvulla ja kasvatustieteisiin 1980 -luvulla. Hiljaiselle tiedolle on ominaista, ettei sen omaksumiseksi riitä ohjeiden mieleenpainaminen tai tiedollisten rakenteiden oppiminen. Se kehittyy omakohtaisen käytännön kokemuksen myötä. Hiljainen tieto on epäonnistumisten, korjauksien, virhepäätelmien ja muuttuneiden käsitysten kokonaistulos.

Hiljainen taitotieto (jota käsitettä tässä käytetään painottamaan, että kyseessä on osaaminen, taito, jota tieto ohjaa) on ei-kielellistä tietoa. Sen vastakohtana on kielellinen tieto, joka kyetään ilmaisemaan väitelauseiden muodossa (Niiniluoto 1989). Yksilö osaa, esimerkiksi, käyttää kieltä mutta ei osaa ilmaista kielen käyttämisen sääntöjä.

Hiljainen taitotieto on osaamisen, työtehtäviin sekä toimintakontekstiin tässä ja nyt kytkeytyvän taidon perusta. Se on tekemisen taitoa ja osaamisen vaistoa. Hiljaisen taitotiedon siirrettävyys organisaation jäseneltä toiselle on vaikeaa, hidasta ja osittain ennakoimatonta. Tämä siirrettävyys perustuu ilmeisesti pitkälle sosiaalisen oppimisen eri muotoihin (jäljittelyyn, mallioppimiseen ja samaistumiseen).

Oppiminen on tällöin kokonaisvaltaista - taitojen, asenteiden ja suhtautumistapojen omaksumista. Nämä kokonaisvaltaiset mallit tahi rakennelmat ikään kuin ujuttautuvat yksilöön. Jos laadukkaan oppimisprosessin kriteeriksi hahmotetaan oppijan tietoisuuden kehittyminen, voidaan näitä oppimisprosesseja pitää alkeellisina. Ne ovat kuitenkin elämää itseään ja vaikuttavat esimerkiksi ammatillisen identiteetin muodostumiseen sekä organisaatioon sitoutumiseen. 


\author{
Kaksi esimerkkiä - ketunhäntä kainalossa \\ - selventänee asiaa.
}

(1) Taloushallinnon ammattilainen kuvasi omaa suhdettaan talonsa kirjanpidon virheisiin, joita aina silloin tällöin paljastui. "Toki meillä niitä ohjeita ja kädestä pitäen neuvoja on, joiden avulla virhettä voidaan lähteä metsästämään... Minä en kuitenkaan niitä käytä... Minulla on vaisto, missä virheen pitää piillä... Ja mä olen huomannut, että aika usein vaisto osuu oikeaan"

(2) Kokenut kirvesmies ja aloitteleva kirvesmies työskentelevät rakennuksilla usein parina. Keskustelin aloittelevan kirvesmiehen kanssa ja hän totesi "Tomppa (kokeneempi kirvesmies) tekee parempaa ja nopeampaa jälkeä... Mutta minä olen huomannut sen, että kun Tomppa tekee sutta, niin minä olen parempi keksimään korjaustavan”.

Kummassakin tapauksessa osaamisen kielellistäminen yhteistoiminnassa muiden kanssa olisi hyvä keino (1) lisätä organisaation yhteisesti omaaman taitotiedon osaamisen määrää ja laatua sekä (2) ehkäistä yksilötasolla hiljaisen taitotiedon mukanaan kantamia rajoituksia. Missä se ketunhäntä sitten on? Kyse ei ollut tutkimushaastatteluista, vaan normaaleista keskusteluista, jotka visusti mieleeni painoin.

Esimerkeissä näkyvät monet hiljaisen taitotiedon piirteet. Työskentelyprosessi nopeutuu. Vuosien myötä kehittyvä osaaminen on tiettyyn tilanteeseen ja siinä toimimisen tapoihin kytkeytyvää - tuskin tilanteesta toiseen siirtyvää. Lisäksi se on yksilöllistä osaamista. Kerran muotouduttuaan tiettyyn toimintakontekstiin sopivaksi, on hiljainen taitotieto itseään toistavaa, rutiinin omaista ja poikkeavaan, yllättävään tilanteeseen vaikeasti sovellettavaa.

Hiljainen taitotieto avaa henkilöstön kehittämiseen uuden näkökulman. Työura on nähtävä ajassa etenevänä ilmiönä, jossa vallitsevat tietyt säännönmukaisuudet. Uran alkuvaiheessa osaamisen haasteet kohdentuvat kahtaalle: 1) mikä on tämä ympäristö, toimintatodellisuus, jossa työtäni teen ja 2) miten tehtäväni teen.

Työsuoritukseen liittyvät osaamisen tarpeet ovat tilannekohtaisia ja konkreetteja, erilaisia selviytymismenetelmiä ja temppujen hallintaan painottuvia (miten -tietoa, Ryle 1947 tai teknisen oppimisintressin mukaista osaamista, Mezirow 1990, tiedon jaotteluista myös Niiniluoto 1989 ja Sarvimäki 1988).

Mikäli työtehtävät pysyvät muuttumattomina, tavoitetaan niiden vaatima taitotieto yleensä muutamassa vuodessa. Yksilö on kasvanut työtehtäviinsä - hän hallitsee ne. Hänelle on kertynyt mittava määrä tekemisen taitoa ja osaamisen vaistoa. Se ei kuitenkaan ole jäsentynyt hallittaviksi kokonaisuuksiksi. Tiedostamisaste on vähäinen, jonka vuoksi taitotieto on staattista, paikallaan pysyvää (Sköld 1989). Näin hiljainen taitotieto kääntyy kehityksen esteeksi.

Kun tehtävien vaatima taitotieto on saavutettu, ei työ enää itsessään tarjoa oppimishaasteita. Leipiintyminen ja tympääntyminen uhkaavat, ja yksilön suoritustaso jää hänen maksimitasoaan heikommaksi (Ashford \& al. 1989, Varila 1992b). Työuran alkuvaiheessa oppimisen haasteet kohdistuvat miten teen -kysymyksiin. Työuran myöhemmässä vaiheessa painopiste siirtyy miksi teen -kysymyksiin.

Tässä on yksi koulutuksen keskeinen funktio organisaatioiden näkökulmasta. Hiljaisen taitotiedon solmukohdat voidaan avata reflektiivisesti koulutuksessa. Samalla lisätään organisaation yhteisen osaamisen laatua ja määrää. Myös eräillä muilla henkilöstön kehittämisen menetelmillä kyetään reflektiivisyyden haasteisiin vastaamaan (esimerkiksi henkilökierto ja kummijärjestelmät).

Noin kaksikymmentä vuotta taloushallinnon tehtävissä toiminut yksilö lähti henkilökiertoon. Tutkimushaastattelussa hän totesi "Vanhassa työpaikassa itse kehitettyjä järjestelmiä... Ei tule silleen aateltua, että sen vois tehdä toisinkin, semmosia oivalluksia”.

Toistakymmentä vuotta laboratoriohoitajana työskennellyt yksilö, joka lähti vuoden mittaiseen erikoistumiskoulutukseen, totesi haastattelussa "Mä totisesti osasin ne hommat. Tää erikoistuminen on niin kivaa sen vuoksi, että nyt mä joudun pohtimaan myös sitä, miksi mä oon tehnyt niin kuin oon tehnyt". 
Esimerkkien viesti on selvä. Työuran keston myötä oppimisen painopiste siirtyy teknisestä hallinnasta ja miten -kysymyksistä miksi -kysymyksiin. Siirtymän tukeminen tuottaa - edelleen yksilön näkökulmasta - syvällistä ymmärrystä ja vaatii matkan varrella kertyneen hiljaisen taitotiedon jäsentymistä kokonaisuuksiksi, jotka kyetään kielellisesti ilmaisemaan.

Vasta kielellisesti ilmaistavissa oleva taitotieto kyetään organisaatiossa siirtämään yhteiseksi osaamiseksi tahi omaisuudeksi. Henkilöstön kehittämisessä pitkän aikajänteen näkökulmasta on haasteena hiljaisen taitotiedon muodostumisen edistäminen (tietyssä tehtävässä työuran alkuvaihe) ja samanaikaisesti sen kyseenalaistaminen (tietyssä tehtävässä työuran myöhempi vaihe).

Henkilöstön kehittämisen mahdollisuuksia osoittaa se, että näihin haasteisiin voidaan vastata samanaikaisesti. Projekteissa voidaan työryhmä miehittää työuran eri vaiheissa olevilla henkilöillä. Työuran alkuvaiheessa omaavia rutiinit eivät ole vielä kangistaneet - kypsässä harkinnassa sitä vastoin esiintynee puutteellisuuksia. Työuran myöhemmässä vaiheessa olevat omaavat kypsyyden, hiljaisen taitotiedon ja luonnollisesti ovat rutinoituneet. Eri tasoilla olevan hiljaisen taitotiedon kohtaaminen rikastuttaa kumpaakin ryhmää: vasta nousevassa olevan hiljaisen taitotiedon omaksuminen nopeutuu ja kypsynyttä, hiljaista taitotietoa joudutaan toisaalla ajamaan tietoiseksi.

Sama ilmiö toistuu myös esimerkiksi niin sanotussa kummityöskentelyssä tai ohjaajasuojatti -suhteessa (mentor-protege -relationships, aiheesta enemmän Bushard 1991). Onnistuneen työskentelyn tuloksena on niin taidollista, tiedollista kuin persoonallistakin uusiutumista)

\section{Henkilöstön kehittämisen suuntautumisvaihtoehdot}

Kuvattuihin, useimmissa organisaatioissa kohdattaviin henkilöstön kehittämisen haasteisiin kyetään vastaamaan eri tavoin. Näitä vaihtoehtoisia tapoja kutsutaan tässä artikkelissa henkilöstön kehittämisen suuntautumisvaihtoeh- doiksi. Niillä tarkoitetaan kohtuullisen johdonmukaisten ajattelu- ja toimintatapojen kokonaisuutta, joka osaltaan määrittää, miten kehittämisen päämäärä, kohteet ja tulosalueet sekä keinovalikoima hahmotetaan.

Suuntautumisvaihtoehtoja kuvaava luokitus perustuu (1) kehittämisellä tavoiteltavan oppimisen luonteeseen sekä (2) kehittämisen taktiikkaan. Kehittämisen päätavat jaetaan formaaliin ja informaaliin kehittämiseen. Formaalilla kehittämisellä tarkoitetaan lähinnä perinteistä henkilöstökoulutusta, johon yksilö osallistuu työstään irrottettuna. Informaalilla taas ymmärretään erityisesti työssä tapahtuvaa oppimista. Se kattaa työn suorittamisen vaatiman taitotiedon soveltamisen konkreetissa toimintatodellisuudessa, laaja-alaisemman 'talon todellisten' toimintatapojen tuntemisen ja vaaditun, 'oikeaksi' hahmotetun suhtautumistavan.

Suuntautumisvaihtoehdot eivät sulje toisiaan pois. Kyse on painopisteen asettamisesta - miten eri mahdollisuudet kombinoidaan optimaalisesti. Nelikentän käyttöä ja toivoakseni myös käyttöarvoa havainnollistaa seuraava kysymyssarja:

\begin{tabular}{lll}
\hline \multicolumn{2}{l}{$\begin{array}{l}\text { Kehittämisen } \\
\text { taktiikka }\end{array}$} & \multicolumn{2}{c}{ Oppimisen luonne } \\
Ennakoitu & Ennakoimaton \\
\hline Formaali & $\begin{array}{l}\text { Henkilöstökou- } \\
\text { lutus: työn } \\
\text { vaatima taito } \\
\text { ja tieto }\end{array}$ & $\begin{array}{l}\text { Henkilöstökoulutuk- } \\
\text { sen piilo-opetus- } \\
\text { suunnitelma }\end{array}$ \\
& $\begin{array}{l}\text { Työn myötä opi- } \\
\text { taan vakiintu- } \\
\text { neet käytänteet }\end{array}$ & $\begin{array}{l}\text { Innovoivat, yksilöl- } \\
\text { liset työhön, sen } \\
\text { kehittämiseen ja } \\
\text { organisaatioon suh- } \\
\text { tautumisen tavat }\end{array}$ \\
\hline
\end{tabular}

Taulukko 1. Henkilöstön kehittämisen suuntautumisvaihtoehdot

1) Kannattaisiko työuran alkuvaiheessa painottaa informaalia taktiikkaa ja ennakoitavaa oppimista? Millaiset tietorakenteet ja osaamishaasteet edellyttävät formaalin taktiikan käyttöä työuran alkuvaiheissa? 
2) Kannattaisiko työuran myöhemmässä vaiheessa, jolloin piilevä, hiljainen taitotieto on kehittynyt kukoistukseensa, painottaa toisaalta informaalista taktiikkaa ja ennakoimatonta oppimista sekä toisaalta tukea osaamisen tiedostumista kielellisiksi, kognitiivisiksi kokonaisuuksiksi esimerkiksi pitkillä ammatillisilla koulutusohjelmilla?

3) Miten työuran eri vaiheissa olevien yksilöiden välille saadaan taitotietojen, asenteiden ja tahdon sekä myös työhön liittyvän habituksen ennakoimatonta ristipölytystä siten, että organisaatiossa esiintyvän yhteisen osaamisen määrä ja laatu kasvaa?

Piilo-opetussuunnitelman käsitettä on kommentoitava tarkemmin, koska se lienee monelle lukijalle entuudestaan tuntematon. Sitä on tavallisesti käytetty yleissivistävän peruskoulutuksen yhteydessä - on kysytty, mitä muuta koulussa opitaan kuin oppisisältöjä. Siellä opitaan kunnioittamaan työn välttämättömyyttä, auktoriteetteja, pilkkomaan elämä kellon mukaan erillisiin, toisiinsa liittymättömiin osiin, opitaan kärsivällisyyttä ja uutteraa odotusta sekä "löydetään" oma tuleva paikka yhteiskunnassa. Näin piilo-opetussuunnitelma tuottaa oppilaaseen velvollisuudentuntoisen, kärsivällisen ja täsmällisen palkkatyöläisen ominaisuudet (Järvi 1988).

Henkilöstökoulutuksessa piilo-opetussuunnitelma on toisenlainen, tavallaan pinnallisempi. Periaatteessa sekin tavoitetaan kysymällä, mitä muuta henkilöstökoulutuksessa oppiaineksen ohella opitaan: käyttökelpoisia sosiaalisia suhteita, ennakoimatonta mutta konkreettia tietoa työelämän tilasta ja asioiden hoidosta muissa organisaatioissa sekä yleisempiä aineksia työhön liittyvien käsitysten muodostamiseen.

Näitä asioita opitaan tauoilla tahi internaattikoulutuksessa vapaa-ajalla. Kurssiarviointina todetaan usein "sisältö oli hyvää mutta varsinainen anti muodostui vapaissa keskusteluissa". Lisäksi henkilöstökoulutuksen organisointi ja opetukselliset ratkaisut ovat jo sinänsä viestejä, piilo-opetussuunnitelmaa puhtaimmillaan.

\section{Lyhyt ja pitkä aikajänne tukevat toisiaan}

Henkilöstön kehittämisessä on aina tilannekohtaisesti ratkaistava, mihin painopiste kulloinkin asetetaan - tuetaanko ennakoitavaa vai ennakoimatonta oppimista. Kyse on myös syvällisemmästä ilmiöstä; karkeasti ilmaisten valinta tehdään sen välillä, kitketäänkö vai lannoitetaanko. Molemmat ovat hyvän ja ammattitaitoisen, viitseliään viljelyn välttämättömiä keinoja.

Kasvatustieteellisesti problematiikkaa lähestytään kasvatuksen määritelmien tarkastelun avulla, jotka voidaan jakaa avoimiin ja suljettuihin. Suljettu kasvatuksen määritelmä on silloin, kun kasvatuksen päämäärä hahmotetaan ulkopuolisin, kasvatettavaan itseensä liittymättömin kriteerein. Esimerkiksi "kasvatus on johdonmukaisuuteen pyrkivää toimintaa kasvatettavan persoonallisuuden, valmiuksien tai yhteisöön sopeutumisen muuttamiseksi edulliseksi katsottuun suuntaan tai säilyttämiseksi tilassa, jota pidetään edullisena" (Nurmi 1983, 61).

Avoin kasvatuksen määritelmä on, jos siinä lähinnä vain tunnistetaan kasvatukselle luonteenomaisia piirteitä. Esimerkiksi "kasvatus on kasvamaan saattamista ja tämä merkitsee, että se on luonnollisen, selittämättömän mutta ilmauksissaan täysin selvän kasvamisvoiman tielle sattuvien esteiden poistamista, suotuisien olosuhteiden luomista itsestään tapahtuvalle kasvamiselle" (Hollo 1955,22)

Henkilöstön kehittämisen suuntautumisvaihtoehdot ovat rinnakkaisia, limittäisiä ja sisäkkäisiä. Henkilöstön kehittämisen lähtökohtana on tavallisesti välittömän hyödyn saavuttaminen: millaisia uusia pätevyyksiä, valmiuksia ja taitotietoja henkilöstö tarvitsee, jotta työ voidaan tehdä aiempaa tehokkaammin.

Henkilöstön kehittämisen vaikutukset ennakoidaan tarkasti ja itse kehittämisprosessi suunnitellaan huolellisesti askel askeleelta eteneväksi. Tällöin työskennellään ennakoitavassa tulevaisuudessa. Kehittämisen tulokset voidaan (periaatteessa) mitata suhteuttamalla ne kriteeriin. Tämä on henkilöstön kehittämisen toinen puo- 
li, joka perusolemukseltaan vastaa hyvin kasvatuksen suljettua määritelmää.

Henkilöstön kehittämisen toinen puoli on, miten henkilöstö voimavarana, inhimillisenä resurssina pidetään jatkuvassa tuottavuuden tilassa - miten inhimillinen pääoma uusiutuu keskimäärin yli kolmekymmentä vuotta kestävän työuran kuluessa; vai uusiutuuko ylipäätään. Kyse on kehittymisvirikkeiden tarjoamisesta, jopa niin ettei virikkeen vastaanottajaa tai vaikutuksia kyetä ennustamaan. Keskeistä on muistaa kysyä, ovatko työtehtävät ihmisen mittaisia.

"Marco Polo kuvailee sillan kivi kiveltä. Mutta mikä kivi kannattaa siltaa? kysyy Kublaikaani.

- Siltaa ei kannata tämä tai tuo kivi, Marco vastaa, - vaan kaaren linja, jonka ne muodostavat.

Kublai-kaani on hiljaa ja miettii. Sitten hän lisää: - Miksi puhut minulle kivistä? Minua kiinnostaa vain kaari.

Polo vastaa: - Ilman kiviä ei ole kaarta." (Italo Calvino, Näkymättömät kaupungit)

Uskallammeko me - kehittäjät ja kehittämisen tutkijat - kohottaa katseemme edes joskus kaareen. Kokemukseni mukaan emme. Organisaation kivimuurin taakse on helppo suojautua. Pitkänen (1988) kysyy ilmeisen aiheellisesti, milloin ollaan valmiita keskustelemaan aiheen "ihminen uudistuvassa työelämässä" ohella tai sijasta aiheesta "ihminen työelämässä" ja milloin vihdoin aiheesta "uudistuva ihminen". Tehokas, maksimaaliseen vaikuttavuuteen yltävä henkilöstön kehittäminen on väistämättä kaaren hallintaa kivien pinoamisen ohella.

\section{LÄHTEET}

Ashford, B. \& Lee, R. 1990. Defensive Behaviors in Organizations: a Preliminary Model. Human Relations 43, 621-648.

Bandura, A. 1989. Self-Regulation of Motivation and Action through Internal Standards and Goal systems. Pervcin, L. (ed) Goal Concepts in Personality and Social Psychology. New York: Lawrence Erlbaum, 19-85.

Bushard, S \& al. 1991. The Mentor/Protege Relationship: a Biological Perspective. Human Relations 44, 619-640.

Calvino, I. 1976. Näkymättömät kaupungit. Tammi: Helsinki.
Deci, E., Wallrank, R. \& al. 1991. Motivation and Education: the Self-Determination Perspective. Educational psychologist 26, 325-346.

Hollo, J. 1952. Kasvatuksen maailma. Porvoo: WSOY.

Järvi, P. 1988. Koulun penkiltä palkkatyöhön: vangit, koulu ja työ. Kasvatus 19, 183-189.

Koskinen, I. 1990. Hiljainen tieto. Nordisk Pedagogik 10, 180-181.

Mezirow, J. 1990. Fostering Critical Reflection in Adulthood: A Guide to Transformative and Emancipatory Learning. San Francisco: Jossey-Bass.

Molander, B. 1990. Kunskapers tysta och tystade sidor. Nordisk Pedagogik 10, 99-115.

Niiniluoto, I. 1989. Informaatio, tieto ja yhteiskunta. Filosofinen käsiteanalyysi. Helsinki: Valtion painatuskeskus.

Nurmi, K. 1983. Johdatus kasvatuksen filosofisiin ja historiallisiin perusteisiin. Helsingin yliopiston Lahden tutkimus- ja koulutuskeskus oppimateriaaleja 1.

Parkes, K. 1991. Locus of Control as Moderator: An Explanation for Additive versus Interactive Findings in the Demand-Disc- retion Model of Work Stress. british Journal of Psychology, 82, 291-312.

Pitkänen, P. Ihminen uudistuvassa työelämässä. Aikuiskasvatus 8, 4-12.

Polanyi, M. 1966. The Tacit Dimensions. London: Routledge \& Kegan Paul.

Ropo, E. 1991. Opettajaeksperttiyden kehittyminen - tutkimus- tuloksia ja näkökulmia. Aikuiskasvatus 11, 153-163.

Ryle, G. 1947. The Concept of Mind. London: Hutchinson.

Sarala, U. 1991. Laatupiirit oppivina työryhminä. Aikuiskasva- tus 11, 164-171.

Sarvimäki, A. 1988. Knowledge in Interactive Practice Disciplines. Research Bulletin 68. Department of Education. University of Helsinki.

Sköld, M. 1989. Everyday Learning: the basis of Adult Education. Leymann, H. \& Kornbluh, H. (ed) Socialization and Learning at Work. A New Approach to the Learning Process in Workplace and Society. Athenaeum Press: Newcastle, 103-118.

Tough, A. 1982. Intentional Changes. Chigago: Follett.

Varila, J. 1992. Työmarkkinakelpoisuus ja työssä oppiminen. Helsinki: Valtionhallinnon kehittämiskeskus.

Varila, J. \& Kallio, K. 1992. Työura, pysyvyys ja muutos. Hen- kilöstön kehittämisen teoriaa kohden: silmäys pysyvyyden ja muutoksen prosesseihin. Helsinki: valtionhallinnon kehit- tämiskeskus.

Vesala, K. 1991. Kontrolliodotusten käsite ja kulttuuriset premissit. Psykologia 26, 366-374. 